\title{
Classroom Authentic Assessment Strategies and Tools used by English Language Teachers in Jordan
}

\author{
Dr. Samer M. Al-Zoubi \\ Department of English Language and Literature \\ Faculty of Arts and Educational Sciences \\ Ajloun National University \\ Jordan
}

\begin{abstract}
The study aimed at investigating the degree of using authentic assessment strategies and tools by English language teachers at Al Korah Directorate of Education in Jordan. The study participants consisted of (39) male and female English language teachers chosen randomly. To achieve the objectives of the study, a questionnaire was developed consisted of 28 forms of authentic assessment strategies and tools. The results of the study revealed that the degree of teachers' using authentic assessment strategies and tools was moderate (means 2.65). Results also showed that there were no statistically significant differences in the degree of teachers' using authentic assessment strategies and tools related to gender. Whereas, the results presented that there were statistically significant differences related to the effect of teaching experience in favour of highly experienced teachers and to the effect of the training courses in favour of teachers who had more than 3 training courses. Recommendations were offered in light of the study results.
\end{abstract}

Keywords: Authentic assessment, self-reflection, classroom observations, portfolio, rubric, checklist

\section{Introduction}

The progress of nations is strongly measured by its educational system. The more effective this system is; the more it contributes to qualify and raise individuals to contribute to the development and prosperity of their communities and countries. However, teaching and learning must be meaningful and meet the needs of learners so that many countries strive to reform their educational systems to keep up with the latest progress in the field of education. In fact, students' learning is a continuous process that has to be frequently assessed, so their progress should be continually evaluated. In general, any assessment tool used by teachers can present a clear idea about learner's achievement on a particular situation so that it will be different from day to day depending on the purpose of the assessment, the conditions in which the assessment is performed, the nature of the assessment task, the learner's preparation and the learner's motivation and engagement. Thus, assessment strengthens teacher and student's knowledge. (Bell, B. \& Cowie, B. 2001.)

Mainly, the assessment of students' learning is one of the most important stages of the learning process and is the most relevant to educational development, which is sought by many educational systems. Assessment is a common tool used in education that requires concentration on improving the teaching and learning processes as well as it is crucial in the classroom that proves whether teachers' goals meet the instructional needs or not. There are many common terms used by teachers to describe students' performance such as test, exam, measurement, assessment, and assessment. These terms may be used interchangeably to refer to the practice of determining learners' proficiency in a variety of contexts. Assessment can be defined as an ongoing process including a lot of techniques such as making an oral judgment of a student's response or writing down a phrase to comment on a student's essay, (Brown \& Abeywickrama. 2010). Thus, the assessment of student learning is one of the most important stages of the learning process and it is related to educational development which many educational systems seek. Since it is a means that enables those who are involved in the learning and teaching process to judge its effectiveness in terms of the outcomes required and its suitability to students' levels, growth, abilities and multiple skills.

However, assessment is an integral part of teaching and learning so assessment information is best described as a process used by teachers to modify their teaching strategies, and by students to adjust their learning strategies. Assessment should be fair, valid, suited to the purpose and measure progress, not just achievement. Though, assessment in its modern sense goes beyond the traditional understanding of the process of assessing student learning, based on demonstration individual differences or skills, measured by arbitrary scores that do not often reflect students' abilities related to higher- thinking processes, make judgments, decision-making and problem-solving. These skills enable students to cope with changes accelerated, at a time when information technology and developments have become a feature of this era. ( Elwood \& Klenowski, 2002). 
The assessment process within an educational setting typically includes the following key elements: defining the purposes of the assessment, constructing or selecting assessment methods to collect evidence of learning, interpreting assessment outcomes collected, grading decision making, recording assessment information, and reporting assessment results to relevant stakeholders comprising students, parents, administrators, potential employers and teachers themselves Moreover, there is agreement that the assessment process has to cover validity and reliability characteristics, given as they play a crucial role in providing accuracy, fairness, and appropriateness of the interpretations and the uses of assessment results (Cizek, 2009\& Miller et al., 2013).

The assessment, which takes into account the trends of the modern assessment, is called the authentic /alternative assessment. It is defined as an assessment that reflects the achievements of the learner and measures them in real situations, which makes students engage in meaningful and useful tasks. Besides, it develops students' ability to think critically, which helps them to process, critique, and analyze information and it documents the link between learning and teaching. Therefore, the use of authentic /alternative assessment strategies and tools by teachers makes their assessment of the students' learning process actual and realistic and provides multiple learning opportunities to their students. Most authentic /alternative assessment strategies require students who have higher levels of thinking skills, problem-solving, and creativity. (Moon, Brighton, Callahan \& Robinson, 2005) .

However, the authentic assessment concept goes beyond the traditional understanding of the process of assessing students' learning, which is based on showing individual differences or skills, measured by arbitrary methods that do not often reflect the students' high thinking levels. Consequently, authentic assessment is the actual assessment of students' performance to decide whether the students can apply what they have learned in real-life situations or not as well as having the ability to be creative and enabling the students to deal with rapid changes in the learning process. The educational assessment in its new trend includes strategies of alternative assessment based on the scientific, methodological basis, and on the authenticity of what the students have learned, in a way that ensures the quality of the educational process and its outputs in terms of the learner's reach for learning purposes and outcomes. ( Hallam and Brookshire, 2002 \& Marzano, 2002).

The use of authentic assessment strategies and tools in EFL classrooms is increasing. This is maybe due to the benefits that this kind of assessment has for teachers and students. As the authentic assessment strategies and tools replicate real-world communication contexts and situations outside the classroom, they measure students' ability to use English in real-life situations. Besides, authentic assessment is a diagnostic tool that is carried out continuously over a period of time rather than restricted to the end of a course or a year. In addition, authentic assessment is student-centered. This helps students to be more involved in their learning and gives them a sense of control for their own learning (Richards \& Renandya, 2002).

Additionally, authentic assessment strategies and tools, such as peer assessment and self-assessment train students to assess their performance and examine their own learning progress, which enables them to take some accountability of their own learning. ( Opp-Beckman \& Klinghammer 2006). Furthermore, it offers a wide range of assessment possibilities to address students' different learning styles. Finally, it provides information on the strengths and weaknesses of each individual student. This can direct teachers and students to the areas that need improvement. (Huerta-Macías, 2002).

\section{Background of the Study}

Jordan is one of the growing countries in the world in the field of education. The education system starts at age four with preschool, followed by basic education for grades 1-10 and secondary education, which consists of 1st Secondary and 2nd Secondary grades. Basically, students' learning is a continuous process that has to be frequently assessed, so their progress should be continually recorded. Student knowledge is evaluated using a variety of different student standardized assessments. Recently, Jordan has carried out many educational reforms by applying modern methods in its educational system of teaching such as applying authentic /alternative assessment that aims to make the learner an active participant in the learning process rather than receiving knowledge without efficiency (MoE ,2004).

In 2004, guided by the new curriculum and the Education Reform for Knowledge Economy ( ERfKE) assessment framework was developed for classrooms that introduced new assessment tools and concepts. The strategy introduced "authentic assessment," which uses five different methods to assess students at the classroom level and aimed to transform the traditional system from "assessment of learning" to "assessment for learning". The Ministry of Education, in Jordan, adopted new assessment strategies and tools, called authentic /alternative assessment, which can be summarized as follows:

\section{A-Authentic Assessment Strategies}


1. Performance-based assessment: students demonstrate how to use skills in real-life situations through simulations or presentations.

2. Pencil-and-paper assessments: Students take tests, quizzes, and exams.

3. Communication: Students are tested via interviews or question-and-answer sessions in order to assess their reasoning and problem-solving abilities.

4. Classroom observations: Teachers observe students' behavior and progress.

5. Self-reflection: Students diagnose their own strengths and weaknesses in order to identify their needs. (MoE ,2004).

\section{B - Authentic Assessment Tools}

1- Checklist: It includes a list of actions or behaviors monitored by the teacher or learner in carrying out one or more educational tasks or skills.

2 - Rating Scale: It based on the segmentation of the educational task or skill to be assessed into a set of tasks or skills.

3 - Rubric : Teachers' awareness of the implications of this strategy (conference, interview, questions, and answers) and associated assessment tools (logbook description) can benefit teachers in planning the lesson.

4 - Anecdotal Records: It provides a clear picture of the overall developmental aspects of the learner through a continuous description of what has been observed on its performance.

5 - Learning Log: The students' written expressions of things they have read, watched or learned. It provides the teacher with an opportunity to learn about the students' opinions and responses ( National Assessment Team, 2004).

\subsection{Statement of the Problem}

In many countries, the main aim of the educational assessment is to measure the learning outcomes. As a result, recent trends in using authentic assessment strategies and tools believe that tests are not the only form of the students' assessment (Abuzina, 2003). systems are witnessing a comprehensive development of the concept of evaluating students' learning strategies and tools. Teachers of different specializations are required to use modern and varied assessment strategies. Not only using written tests, which they used to assess student's achievement but there is an inconsistency in using authentic /alternative assessment strategies and tools in the classroom. So, this study comes to reveal the degree of using authentic assessment strategies and tools by English language teachers such as performancebased, pencil and paper, observation, communication, and reflection assessment. Moreover, this study showed the degree of using authentic assessment tools like a checklist, rating scale, rubric, learning log and anecdotal records.

\subsection{Significance of the Study}

The present study is significant for these reasons :

1. It identifies the most important authentic assessment strategies and tools used by Jordanian English language teachers in evaluating the learning process.

2. It investigates the impact of several variables specific to English language teachers about the degree of using authentic assessment strategies and tools including gender, years of experience, and training courses.

3. It addresses the topic of authentic assessment strategies and tools as one of the main topics in the learning process.

4. It provides the officials in the Ministry of Education in Jordan (supervisors, Curriculum Department, Managing Directorate of Examinations and Tests) with the reality of using authentic assessment strategies and tools, and identifies less commonly used strategies to focus on.

\subsection{Purpose of the study}

The main aims of this study are:

1. To identify the practices and purposes of using authentic assessment strategies and tools in Jordan.

2. To examine the degree to which English language teachers use authentic assessment strategies and tools in Jordan.

3. Determining to what extent English language teachers use authentic assessment strategies and tools according to several variables such as gender, years of experience, and training courses.

\subsection{Questions of the Study}

This study tries to answer the following questions:

1. What is the degree of using authentic assessment strategies and tools by Jordanian English language teachers?

2. Are there any statistically significant differences in using authentic assessment strategies and tools among Jordanian English language teachers attributed to the teacher's gender (male and female)?

3. Are there any statistically significant differences in using alternative assessment strategies and tools among Jordanian English language teachers attributed to the teaching experience? 
4. Are there any statistically significant differences in using authentic assessment strategies and tools among Jordanian English language teachers attributed to specific training courses received?

\section{Literature Review}

Several studies are investigating the impact of authentic assessment strategies and tools on the learning process. Nasr (1998) carried out a study aimed at determining the extent to which Arabic language teachers used authentic assessment and tools for evaluating students in public schools in Jordan. The results showed that teachers used all types of authentic assessment strategies and tools, but they vary in degree of use. Pencil and paper strategy got the highest averages, while peer assessment received the lowest averages. The results also indicated that there are statistically significant differences attributed to gender in favor of females teachers and to experience in favour of highly experienced teachers.

Adams \& Hsu (1998) conducted a study on authentic assessment and tools used by teachers. The study sample consisted of (296) teachers from grade one to four. The results of the questionnaire analysis showed that the highest averages of authentic assessment and tools used by teachers from the teachers' perspective are observation, performance-based, and problem-solving strategies. From the teachers' point of view, the least important alternative assessment strategy is using a pencil and paper strategy.

Lanting's (2000) study which aimed to identify the authentic assessment strategies and tools used by four primary school teachers to assess their students' reading and writing skills. The results illustrated that teachers used observation and interviews in which they used a correction guide to evaluate their students and they did not use the portfolio and self-assessment strategies. The study also showed that the teachers focused on aspects of strengths in students' performance and not on their weaknesses.

Fritz's (2001) study aimed at identifying teachers' practices in using portfolios as authentic assessment strategies to evaluate their students' achievement. Each student selected seven tasks of their work to be evaluated. The results showed that $50 \%$ of teachers with more than three years of experience used portfolios in evaluating their students' achievement. The results also indicated an improvement in students' performance, as well as the number of teachers who used portfolios, increased annually.

Aman (2001) conducted a study aimed at investigating the impact of using authentic assessment and tools on students' achievement at the end of the first cycle of basic education in Mathematics in Bahrain. The results indicated that there were statistically significant differences in students' achievement after applying authentic assessment strategies and tools in mathematics. The results indicated that there were no statistically significant differences in students' achievement according to gender in using authentic assessment strategies and tools in mathematics.

Kharabsheh (2004) investigated the impact of using authentic assessment strategies and tools on students' performance of the ninth grade students in writing skill compared to the traditional assessment strategies. The results showed that there were statistically significant differences in favour of the experimental group that using authentic assessment strategies while the results did not indicate any statistically significant differences attributed to the interaction between gender and the authentic assessment strategies used.

Butler (2009) reviewed studies conducted on teacher-based assessment in three Asian countries: Korea, Taiwan, and Japan. He emphasized the importance of central specifications of authentic assessment procedures and noted that such guidelines existed in none of the three countries. In Korea and Taiwan, the government recommended that teachers should apply teacher-based assessments or random observation-based assessments and portfolios to assess their students' performance. However, classroom observations revealed that the teachers found it challenging to use these forms of authentic assessment, which had been traditionally less used in East Asia.

It is clear from the previous studies that teachers employed all types of alternative assessment strategies and tools, but they vary in the degree of use. Moreover, these studies investigated the independent variables such as gender, years of experience, training courses, academic level and school type.(Fritz, 2001 ; Adams \& Hsu,1998 ;Lanting, 2000 ;Kharabsheh, 2004 ; Aman ,2001 and Butler ,2009).

\section{Methodology and Procedures of the Study}

\subsection{Participants}

The study participants consisted of (39) male and female English language teachers teaching in eight public schools (four schools for boys and four schools for girls) chosen randomly from Al Korah Directorate of Education. They distributed according to the following independent variables: Gender, years of experience and training courses, as shown in Table (1). 
Table( 1). Distribution of participants Variable

\begin{tabular}{|l|l|l|l|}
\hline \multicolumn{2}{|c|}{ Variable } & No. & Percentage \\
\hline \multirow{3}{*}{ Gender } & Male & 18 & 46.153 \\
\cline { 2 - 4 } & Female & 21 & 53.846 \\
\hline \multirow{2}{*}{ Teaching Experience } & Less than10 years & 17 & 43.589 \\
\cline { 2 - 4 } & More than10 years & 22 & 56.410 \\
\hline Training Courses & Less than3 & 16 & 41.025 \\
\cline { 2 - 4 } & More than3 & 23 & 58.974 \\
\hline Total & & $\mathbf{3 9}$ & $\mathbf{1 0 0 \%}$ \\
\hline
\end{tabular}

Table (1) showed the variables of the study. According to gender, the participants were 39 ( 18 males and 21 females). Concerning teaching experience, 17 participants had less than10 years and 22 participants had more than 10 years. Regarding the training courses, 16 participants had less than 3 and 23 had more than 3.

\section{4 .2 Instrument of the Study}

In this study, the researcher used quantitative research (Analytical Descriptive Approach). He developed a questionnaire survey to answer the study questions by investigating the degree of using authentic assessment strategies and tools as well as identifying if there are any statistically significant differences at the means degree $(\alpha=0.05)$ of using authentic assessment strategies and tools depending on several independent variables such as gender, years of experience and training courses among English language teachers at Al Korah Directorate of Education in Jordan. The final questionnaire consisted of 28 forms of authentic assessment strategies and tools items. It was a 5-point Likert scale: Always, often, sometimes, rarely and never.

\subsection{Validity of the Instrument}

The researcher checked the validity of the questionnaire (checking if it measures what is it meant to measure), it was submitted to a group of specialists: Three faculty members with PhDs at the Department of English Language and Literature at Ajloun National University, three experienced teachers and two supervisors of English at Al Korah Educational Directorate. After approving its suitability for the purpose of the study, the researcher took the suggested modifications into consideration and so modifications were made.

\section{4 .4 The reliability of the Instrument}

A total sample of (12) English language teachers (6) males and (6) females took part in ensuring the reliability of the questionnaire. Alpha formula was used to determine the reliability of the questionnaire. According to Devellis (1991), good reliability of the questionnaire will be found if the alpha $(\alpha)$ is at least equal $0.70(\alpha \geq 0.70)$. After collecting data from the questionnaires, the data were calculated using SPSS version 17.0 for Windows. The reliability value was found to be $0.84(\alpha=0.84)$, which is higher than 0.70 . Thus, the present questionnaire was reliable and could be used in the main study.

\subsection{Statistical Analysis}

In this study, the researcher used the (SPSS), which stands for (the Statistical Package for Social Scientifics). Means, percentages, standard deviations, and degrees were computed to summarize the students' responses to the questionnaires. Besides, a t-test and the Two-Way Analysis of Variance (ANOVA) were used to answer the study questions concerning gender, years of experience and training courses.

For data analysis, the researcher used the following scale:

- A high degree of using authentic assessment strategies: If the means of teachers' responses are between $3.5-5$

- A moderate degree of using authentic assessment strategies: If the means of teachers' responses are between 2.5 -3.49

- A low degree of using authentic assessment strategies: If the means of teachers' responses are between $1-2.49$.

\section{Results and Discussion}

\subsection{Results Related to the First Question}

- What is the degree of using authentic assessment strategies and tools by Jordanian English language teachers? Means, standard deviations and degree were calculated for each item and the overall score of the questionnaire as shown in table ( 2 ). 
Table ( 2 ): Authentic Assessment Strategies and Tools: Means, standard deviations and degree

\begin{tabular}{|c|c|c|c|c|c|}
\hline $\begin{array}{l}\text { Item } \\
\text { No. }\end{array}$ & $\begin{array}{l}\text { Authentic } \\
\text { Assessment } \\
\text { Strategy }\end{array}$ & Strategy Forms & Means & $\begin{array}{l}\text { Std. } \\
\text { Deviation }\end{array}$ & Degree \\
\hline \multirow{8}{*}{1.} & \multirow{7}{*}{$\begin{array}{l}\text { Performance } \\
\text { Based }\end{array}$} & 1. Performance & 3.2564 & .63734 & Moderate \\
\hline & & 2. Presentation & 2.8718 & .57029 & Moderate \\
\hline & & 3. Demonstration & 3.5385 & .55470 & High \\
\hline & & 4. Speech & 3.5641 & .55226 & High \\
\hline & & $\begin{array}{l}\text { 5.Simulation/Role } \\
\text { Play }\end{array}$ & 1.9897 & .59462 & Low \\
\hline & & 6. Debate & 2.8859 & .68036 & Moderate \\
\hline & & 7.Exhibition & 1.8615 & .55470 & Low \\
\hline & Total & & 2.8525 & .26816 & Moderate \\
\hline \multirow{6}{*}{2.} & \multirow{6}{*}{ Pencil and Paper } & 8.Quizzes and exams & 4.3590 & .58432 & High \\
\hline & & 9. Worksheets & 3.9231 & .83932 & High \\
\hline & & 10. End of Unit Tests & 4.0103 & .60698 & High \\
\hline & & 11. Monthly Test & 4.1282 & .69508 & High \\
\hline & & 12.Open-ended answer & 4.2821 & .55954 & High \\
\hline & & 13.Problem- Solving & 2.7385 & .55470 & Moderate \\
\hline & Total & & 3.9068 & .29235 & High \\
\hline \multirow[t]{2}{*}{3.} & \multirow[t]{2}{*}{ Observation } & $\begin{array}{l}\text { 14.Random } \\
\text { observation }\end{array}$ & 2.3795 & .60139 & Low \\
\hline & & $\begin{array}{l}\text { 15. Systematic- } \\
\text { observation }\end{array}$ & 1.9923 & .65510 & Low \\
\hline & Total & & 2.1859 & .47544 & Low \\
\hline \multirow{4}{*}{4.} & \multirow[b]{3}{*}{ Communication } & 16. Conference. & 2.3256 & .63734 & Low \\
\hline & & 17. Interview & 2.8641 & .64051 & Moderate \\
\hline & & $\begin{array}{l}\text { 18. Questions and } \\
\text { Answers }\end{array}$ & 1.9462 & .58663 & Moderate \\
\hline & Total & & 2.3786 & .42806 & Low \\
\hline \multirow{5}{*}{5 . } & \multirow{5}{*}{ Reflection } & 19.Self-Assessment. & 2.4615 & .64262 & Low \\
\hline & & 20.Peer - Assessment & 2.1436 & .44236 & Low \\
\hline & & 21. Journal & 2.4282 & .57029 & Low \\
\hline & & 22. Student - Portfolio & 2.3231 & .66430 & Low \\
\hline & & 23. Projects & 3.4051 & .86388 & Moderate \\
\hline & Total & & 2.5523 & .30382 & Moderate \\
\hline \multirow{7}{*}{6.} & \multirow{5}{*}{$\begin{array}{l}\text { Assessment } \\
\text { Tools }\end{array}$} & 24. Checklist & 2.9026 & .80736 & Moderate \\
\hline & & 25. Rubric & 1.9974 & .88243 & Low \\
\hline & & 26.Rating Scale & 1.8179 & .60475 & Low \\
\hline & & 27.Anecdotal Records & 1.8027 & .61756 & Low \\
\hline & & 28.Learning Log & 1.7027 & .70178 & Low \\
\hline & Total & & 2.0446 & .34674 & Low \\
\hline & Overall Score & & 2.6533 & 0.88 & Moderate \\
\hline
\end{tabular}

It is obvious from the previous table (2)that the degree of using authentic assessment strategies and tools by English language teachers at Al Korah Directorate of Educational was high for items (8,9,10,11 and 12) all of these items are forms of a pen and paper strategy. This indicated that the degree to which teachers use pencil and paper strategy is still the most frequently used and common in the assessment of student learning. The use of demonstration and speech forms from a performance-based assessment strategy was also high items ( 3 and 4). 
Moreover, the table presented that the degree of using authentic assessment strategies and tools by English language teachers for items $(1,26,13,17,18,23$ and 24$)$ was moderate. In other words, the use of performance, presentation, debate, problem -solving, random observation, interview, questions and answers, peer assessment, journal, project and checklist forms was moderate. The rest forms of using alternative assessment strategies and tools by English language teachers at Al Korah Directorate of Education were low.

In general, the overall means value of the teachers' responses to the questionnaire items was 2.6533 (moderate). This value falls within the period between 2.5 and 3.49 that indicated the degree of using alternative assessment strategies and tools by English language teachers at Al Korah Directorate of Education was moderate.

The findings of this study related to the first question were consistent with the findings of Nasr's study (1998) that teachers used all types of authentic or alternative assessment strategies and tools, but they vary in the degree of use. Pencil and paper strategy got the highest average and was a widely used strategy by teachers. while Systematic observation received the lowest averages. The results of this study were inconsistent with the study of Adams \& Hsu (1998) that showed the least important alternative assessment strategies and tools is using pencil and paper and standardized tests since they had the lowest means from the teachers' point of view. The results of this study also disagreed with Lanting's (2000) study that presented the portfolio and self-assessment had low means that is not widely used by teachers. These results explained that English language teachers preferred to use pencil and paper with all its forms is the most prominent of alternative assessment strategies and tools to enable them of a quantitative assessment of the performance of their students.

\section{5 .2 Results Related to the Second Question}

- Are there any statistically significant differences in using alternative assessment strategies and tools among Jordanian English language teachers attributed to the teacher's gender (male and female)?

Table(3). Means, standard deviations and t-test of the teachers' responses were calculated according to gender for significance of differences between the means

\begin{tabular}{|c|c|c|c|c|c|c|}
\hline $\begin{array}{l}\text { Alternative Assessment } \\
\text { Strategies and Tools }\end{array}$ & Gender & $\mathbf{N}$ & $\mathbf{M}$ & SD & $\mathbf{T}$ & Sig \\
\hline \multirow[t]{2}{*}{ Performance -Based } & Male & 18 & 2.6746 & .32799 & \multirow[t]{2}{*}{.013} & \multirow[t]{2}{*}{.990} \\
\hline & Female & 21 & 2.6735 & .21258 & & \\
\hline \multirow[t]{2}{*}{ Pencil and Paper } & Male & 18 & 3.9167 & .28151 & \multirow[t]{2}{*}{.885} & \multirow[t]{2}{*}{.382} \\
\hline & Female & 21 & 3.8333 & .30277 & & \\
\hline \multirow[t]{2}{*}{ Observation } & Male & 18 & 1.9167 & .49259 & \multirow[t]{2}{*}{-.231} & \multirow[t]{2}{*}{.819} \\
\hline & Female & 21 & 1.9524 & .47183 & & \\
\hline \multirow[t]{2}{*}{ Communication } & Male & 18 & 2.2593 & .42095 & \multirow[t]{2}{*}{.495} & \multirow[t]{2}{*}{.623} \\
\hline & Female & 21 & 2.1905 & .44186 & & \\
\hline \multirow[b]{2}{*}{ Reflection } & Male & 18 & 2.3444 & .27273 & \multirow[t]{2}{*}{.992} & \multirow[t]{2}{*}{.328} \\
\hline & Female & 21 & 2.2476 & .32805 & & \\
\hline Assessment Tools & $\begin{array}{l}\text { Male } \\
\text { Female }\end{array}$ & $\begin{array}{l}18 \\
21\end{array}$ & $\begin{array}{l}1.9333 \\
2.0092\end{array}$ & $\begin{array}{l}.35645 \\
.34300\end{array}$ & -.676 & .503 \\
\hline Total & $\begin{array}{l}\text { Male } \\
\text { Female }\end{array}$ & $\begin{array}{l}18 \\
21\end{array}$ & $\begin{array}{l}2.6746 \\
2.6735\end{array}$ & $\begin{array}{l}.32799 \\
.21258\end{array}$ & .013 & .990 \\
\hline
\end{tabular}

Table (3) presented the number of male teachers was 18 ( means 2.6746) while the number of female teachers was 21 ( means 2.6735). The means of the two groups were approximately equal in using alternative assessment strategies and tools. Now, it can be concluded that there were no statistically significant differences at ( 0.05$)$ attributed to the variable of gender ( male and female) in using alternative assessment strategies and tools by English language teachers at $\mathrm{Al}$ Korah Directorate of Educational. This might be due to the fact that all teachers, males, and females, are subjected to the same educational system as well as all the subjects they teach are similar. Accordingly, the results of this study agreed with the studies of (Aman ,2001; Mafargeh, 2004) while it contradicted with (Barakat, 2010; Nasr's, 1998; Swift, 2002), where the results of their studies indicated that there were statistically significant differences attributed to gender in favour of females teachers regarding the use of alternative assessment strategies and tools. 


\section{5 .3 Results Related to the Third Question}

- Are there any statistically significant differences in using alternative assessment strategies and tools among Jordanian English language teachers attributed to the teaching experience?

Table(4). Means, standard deviations and t-test of the responses according to years of experience and one-way ANOVA results.

\begin{tabular}{|c|l|l|l|l|l|l|}
\hline \multirow{2}{*}{$\begin{array}{l}\text { Teaching } \\
\text { Experience }\end{array}$} & No. & Means & $\begin{array}{l}\text { Std. } \\
\text { Deviation }\end{array}$ & t-value & Sig. \\
\cline { 2 - 7 } & Less than 10 years & 17 & 2.4607 & .3322 & -.812 & .411 \\
\cline { 2 - 7 } & More than 10 years & 22 & 3.6351 & .4621 & -.276 & .783 \\
\hline Total & $\mathbf{3 9}$ & & $\mathbf{3 . 0 9 5 8}$ & $\mathbf{. 5 6 3 2}$ & & \\
\hline
\end{tabular}

It is noted from Table (4) that there were statistically significant differences in the means of using alternative assessment strategies and tools among Jordanian English language teachers attributed to the variable of teaching experience in favour of teachers who had more than 10 years experience ( mean 3.6351) while the mean of teachers who had less than 10 years experience was (2.4607)

The findings of this study were consistent with the findings of Fritz's (2001) that showed $50 \%$ of teachers with more than three years of experience used portfolios in evaluating their students' achievement. The results of this study also agreed with studies' results of (Momany \& Khaza'li, 2010 \& Almola, 2005), which revealed that there were statistically significant differences of such practices that were attributed to the variable of teaching experience to those who had more than 10 years experience. On the other hand, the results of this study contradicted the studies' results of (Barakat, 2010 \& Hamadneh, 2006) which demonstrated that there were no statistically significant differences of such practices that were attributed to the variable of teaching experience to those who had more than 10 years experience. This can be attributed to the fact that the teachers acquire assessment efficiency in small amounts during the years of their service because they actually repeat the same practices regardless of the number of years of experience without the accumulation of qualitative practices. This can be due to the absence of professional growth programs. Furthermore, the teachers with less experience received training courses when they entered the teaching profession so as to increase the necessary skills for teaching and assessment and to remove the differences between them and the teachers who had more teaching experience.

\section{5 .4 Results Related to the Fourth Question}

- Are there any statistically significant differences in using authentic assessment strategies and tools among Jordanian English language teachers attributed to specific training courses received?

Table (5). Means, standard deviations and t-value of the responses according to the number of training courses, and one-way ANOVA results.

\begin{tabular}{|c|l|l|l|l|l|l|}
\hline \multirow{3}{*}{$\begin{array}{c}\text { Training } \\
\text { Courses }\end{array}$} & & No. & Means & Std. D & t-value & Sig. \\
\cline { 2 - 7 } & Less than 3 & 16 & 2.2312 & .6233 & -.512 & .311 \\
\cline { 2 - 7 } Total & More than 3 & 23 & 3.8078 & .9365 & -.376 & .583 \\
\hline $\mathbf{3 9}$ & $\mathbf{3 . 2 6 9 5}$ & $\mathbf{. 7 7 9 9}$ & & \\
\hline
\end{tabular}

Table (5) illustrated the means, standard deviation and t-value for the variable of training courses of both less than 3 (N 16) and more than $3(\mathrm{~N} 23)$. The results of the t-test revealed that there were statistically significant differences at ( 0.05) in the means of Jordanian English language teachers ' responses in using authentic assessment strategies and tools attributed to the variable of training courses in favour of teachers who had more than 3 training courses means (3.8078) high whereas the means of teachers who had less than 3 training courses was (2.2312).

These results agreed with the results of Wilson's ( 2001) study which showed that the teachers who took such training courses were more efficient and effective than the teachers who did not take them because such courses helped them to finish their tasks and to follow the developments of the educational process. Whereas the results of this study contradicted with the results of Barakat's ( 2010) study that indicated there were no statistically significant differences with the assessment practices of the study's sample according to the variable of the number of training courses. This can be related to the fact that the teachers are known by special intellectual characteristics, skills, and personal particular features that enable them to use authentic assessment strategies and tools successfully.

\section{Conclusion}

This study attempted to highlight the importance of using these authentic assessment strategies and tools by English language teachers at Al Korah Directorate of Education to improve the learning process. The findings of this study revealed that teachers used all types of authentic assessment strategies and tools, but they vary in the degree of use. 
In conclusion, the degree of using authentic assessment strategies and tools by English language teachers at Al Korah Directorate of Education was moderate. Moreover, the results showed that there were no statistically significant differences attributed to gender (male and female) in using authentic assessment strategies and tools by English language teachers. Finally, the results showed that that there were statistically significant differences in the means of using authentic assessment strategies and tools among Jordanian English language teachers attributed to the variable of the number of experience years in favour of teachers who had more than 10 years experience as well as the results demonstrated that there were statistically significant differences in the means of Jordanian English language teachers ' responses in using alternative assessment strategies and tools attributed to the variable of training courses in favour of teachers who had more than 3 training courses . In light of classroom assessment, authentic or alternative assessments tend to be more authentic, engaging, challenging and emphasizing deep rather than superficial learning (Hargreaves, Early, \& Schmidt, 2002).

\section{Recommendations}

With reference to the findings of this study, the researchers concluded the following recommendations:

1 - Holding training courses on authentic assessment strategies and tools to those who teach English language since the results of this study indicated that there were statistically significant differences attributed to the impact of training courses in favour of teachers who had more training courses.

2 - Encouraging English language teachers to use all types of authentic or alternative assessment strategies and tools to improve the learning process.

3 - Exposing students to different authentic assessment strategies and tools to help them get rid of their points of weakness and improve their fluency as well as proficiency in English.

4 - Conducting similar studies on a larger sample of teachers from different disciplines and different regions to determine the degree to which teachers use alternative assessment strategies and tools.

\section{References}

Abu Zeina, F .(2003) .School mathematics curriculum and teaching. Kuwait: Al Falah Publishing \& Distribution.

Adams, T. \& Hsu, J.(1998). Classroom assessments: Teachers' conceptions and practices in mathematics. School Science and Mathematics, 98(4), 174-180.

Al-Kharabsheh, B. (2004). The effect of using alternative assessment methods on the performance of ninth-grade students' fundamentals of written expression. Unpublished Master Thesis, University of Jordan.

Allen, D. D. \& Flippo, R. (2002). Alternative assessment in the preparation of literacy educators: responses from students. Reading Psychology, 23, 15-26.

Almola, S. (2005). Design model to evaluate the reality of teaching practices for teachers of physical education at the primary level in the city of Mousel.

Aman, M,(2001).The correlation of student achievement at basic education in mathematics by applying authentic assessment tools: Performance-based strategy, Unpublished Master Thesis, University of Bahrain.

Barakat, Z. (2010). The efficiency of the teacher's practicing questioning skills and his responding to the student's questions and answers in the classroom. Retrieved September 20, 2014. http://www.qou.edu/Arabic/r36_drziadBarakat.htm.

Bell, B. and Cowie, B. 2001The characteristics of formative assessment in science education. Science Education, 85(5): $536-553$.

Butler, Y. G. (2009). How do teachers observe and evaluate elementary school students' foreign language performance? A case study from South Korea. TESOL Quarterly, 43, 417-444.

Brown, H. D., \& Abeywickrama, P. (2010). Language assessment: Principles and classroom practices. White Plains, NY: Pearson Education, Inc.

Cizek, G. (2009). Reliability and validity of information about student achievement: Comparing large-scale and classroom testing contexts. Theory into Practice, 48(1), 63-71.

Elwood, J. \& Klenowski, V. (2002) Creating communities of shared practice: assessment use in learning and teaching, Assessment and Evaluation in Higher Education, 27(3), 243-256.

Fritz, C. A. (2001). The level of teacher involvement in the Vermont mathematics Portfolio Assessment Process and Instructional Practices in Grade 4 Classrooms. Dissertation abstracts, Ph.D., University of New Hampshire, USA. UMI 3006136.

Hallam, R. \& Brookshire, R. (2006). Using authentic assessment to evidence children's progress toward early learning standards. Early Childhood Education Journal, 34(1), 45-51. 
Hamadneh, A. (2006). The Extent to which teachers of the Arabic language and its parameters educational competencies necessary to teach high school literary texts and the extent of their exercise in Mafraq Governorate. Almanarah Journal, 13(1), 1-57.

Hargreaves, A., Early, L., \& Schmidt, M. (2002). Perspectives on alternative assessment reform. American Educational Research Journal, 39, 69-95.

Huerta-Macías, A. (2002). Alternative assessment: Response to commonly asked questions. In J. Richards \& W. Renandya (Eds.), Methodology in language teaching: An anthology of current practice (pp. 338-343). Cambridge: Cambridge University Press.

Jordan, Government of the Hashemite Kingdom of. MoE (Ministry of Education). (2004). "Assessment Strategies and Tools." MoE, Amman, Jordan.

Lanting, A. Y. (2000). An Empirical Study of District-Wide k-2 performance Assessment program: Teacher practices, Information Gained, and use of Assessment Results. Dissertation Abstracts. Ph.D., the University of Illinois At Urbana Champaign, USA.

Lombardi, M.M. (2008). Making the grade: The role of assessment in authentic learning. Educause Learning Initiative. Retrieved from EBSCO Host database at http://www.capella.edu/

Mafargeh, H. (2004). The characteristics of an effective teacher of Islamic education from the point of view of eleventh-grade students in the governorate of Ramallah and Al Bireh (Unpublished master's thesis). Alquds University, Alquds, Palestine.

Ministry of Education, Hashemite Kingdom of Jordan. (2015). "Educational System." http://www.moe.gov.jo/en/.

Momany, A., \& Khaza'li, Q. (2010). The effect of education and teaching experience on primary female teachers' practice of international competencies. Dirasat, Educational Sciences, 37(1), 14-31.

Moon, T., Brighton, C., Callahan, C. \& Robinson, A. (2005). Development of authentic assessments for the middle school classroom. XVI,2/3, 119-133.

Nasr, H (1998). The Extent of Using Assessment methods and tools by Arabic language teachers of Public education in Jordan. Journal of Educational Research Center, Qatar University 13 (7).178-141.

National Assessment Team (2004). Assessment Strategies and Tools: Theoretical Framework. Directorate of Examinations and Tests, Jordan: Ministry of Education.

Opp-Beckman, L. \& Klinghammer, S. (2006). Shaping the way we teach English: Successful practices around the world (Instructor's manual). Washington, DC: University of Oregon

Richards, J. \& Renandya, W. (2002). Methodology in language teaching. Cambridge: Cambridge University Press.

Swift, J. (2002). Wait time and questioning skills of middle school science teachers. Roeper Review, 9(2), 64-66.

Wilson, R. (2001). Conceptualizing and validating teacher questioning skills. Journal of Educational and Behavioral Problems, 8(1), 18-24. 